Dhaka Univ. J. Biol. Sci. 29(2): 165-174, 2020 (July)

\title{
SEQUENCING OF DNA ISOLATED FROM COLORECTAL SAMPLE FIXED IN LIQUID FORMALIN : OBSTACLES AND REQUIRED MODIFICATIONS
}

\author{
Nahid Parvez And MustaK Ibn Ayub* \\ Department of Genetic Engineering and Biotechnology, University of Dhaka, \\ Dhaka-1000, Bangladesh
}

Key words: Sequencing, Formalin fixed tissue, DNA isolation, Colorectal cancer

\begin{abstract}
The necessary modifications in the protocol of general purpose DNA isolation kit to isolate and amplify a target region of genome from colorectal cancer tissues fixed in liquid formalin were made. It is shown that a one hour digestion with proteinase $\mathrm{K}$ yields enough DNA from formalin fixed colorectal tissue for subsequent PCR and sequencing. Moreover, using 100\% ethanol instead of standard 50\% during DNA binding step in the column improves the yield. As DNA fragmentation is unavoidable in formalin fixed tissue, PCR protocol was modified by increasing polymerase concentration to get successful amplification. Following these modifications, two regions of KRAS and BRAF genes were amplified and successfully sequenced from three different patients. These modifications provide a low cost option for Sanger sequencing of DNA isolated from formalin fixed tissue.
\end{abstract}

\section{Introduction}

Cancer is the sixth leading cause of death and accounts for $10 \%$ of all mortality in Bangladesh. Based on two hospital-based cancer registries, nearly $66 \%$ of patients with cancer are estimated to be within the age bracket of 30 to 65 years and constitute the main work force structure in the country. The incidence of cancers is expected to rise from 136,719 in 2015 to 250,726 cases in $2035^{(1)}$. Considering such high risk of cancer related mortality, research on cancer patients in Bangladeshi demands immediate attention.

Cancer research is often based on retrospective studies on large number of samples, as gathering fresh samples in big number is difficult and sometimes impossible. But in common pathology practices, laboratories routinely fix specimens in formalin prior to histological evaluation. These samples form an invaluable resource for molecular studies with clinical correlation. Although formalin is an excellent preservative for maintaining the integrity of tissues, the fixation and subsequent storage leads to nucleic acid degradation and extensive modification that may affect the yield and quality of nucleic

*Author for correspondence: <miayub@du.ac.bd>. 
acids (DNA and RNA) ${ }^{(2,3)}$. One of the common phenomena is the formation of DNAprotein cross links, which are not completely removed by common lysis protocols ${ }^{(4)}$. Formalin-fixation leads to the formation of DNA-protein cross links, which are not completely removed by common lysis protocols. Cross links increase the sensitivity of DNA to mechanical stress and decrease the accessibility for enzymes ${ }^{(5,6)}$. In addition, formalin is oxidized to formic acid which causes DNA depurination and DNA strand breaks $^{(7)}$.

If sequencing of a target genomic region is possible from a formalin fixed sample using the kits designed for fresh tissue, population based retrospective study would be much easier and flexible. Keeping these points in mind, it was aimed at finding necessary modifications of a standard genomic DNA isolation kit for making it more suitable to isolate DNA from formalin fixed sample. This study also found out necessary modifications of PCR amplification protocol to successfully amplify a target region of DNA isolated from formalin fixed tissue.

For DNA isolation, colorectal cancer tissue was selected due to its high prevalence around the world. In Bangladesh it is the most prevalent after lung and breast cancer. Moreover, the detailed molecular pathway is well established for colorectal cancer ${ }^{(8)}$. For PCR amplification, primer was designed to amplify exon 2 of KRAS and exon 15 of BRAF gene. Mutations in these regions make cancer patient resistant to anti-EGFR based therapy ${ }^{(9-12)}$.

\section{Materials and Methods}

Surgical specimens of colorectal cancer patients fixed in liquid formalin were collected from National Institute of Cancer Research and Hospital (NICRH), Dhaka, Bangladesh. Malignant growth of colon was identified based on their growth like a solid tissue mass and absence of characteristic crypts of colon and rectum (Fig. 1). Sections from these surgical samples were stored in $70 \%$ ethanol and transported in an icebox. For long term storage, samples were kept at $-80^{\circ} \mathrm{C}$ in the laboratory.
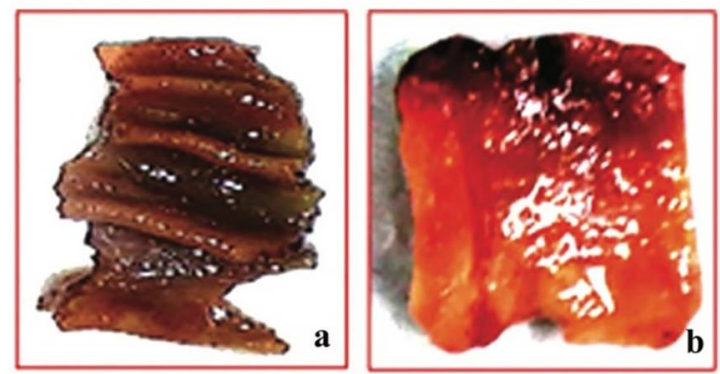

Fig. 1. Surgical sections of colon tissue. (a) Normal colon tissue where regular crypt structures are visible, (b) cancer tissue where the structure has disappeared. These samples were collected from the same patient. 
The GeneJET ${ }^{\mathrm{TM}}$ DNA extraction kit (K0721) was used for DNA isolation from the tissue sample. The kit recommended isolation of genomic DNA from fresh mammalian tissue. In standard protocol, up to $20 \mathrm{mg}$ of mammalian tissue is digested in $180 \mu \mathrm{l}$ of digestion solution and $20 \mu \mathrm{l}$ of proteinase $\mathrm{K}$ by incubating at $56^{\circ} \mathrm{C}$. To obtain a homogeneous mixture $200 \mu \mathrm{l}$ of lysis solution is added. After adding $400 \mu \mathrm{l}$ of $50 \%$ ethanol to the lysate, it is transferred to a GeneJET genomic DNA purification column and centrifuged. The column is washed with $500 \mu$ l of wash buffer I and II by centrifugation for $1 \mathrm{~min}$ at $8000 \times \mathrm{g}$ and for $3 \mathrm{~min}$ at maximum speed $(\geq 12000 \times \mathrm{g})$, respectively. DNA is eluted with nuclease free water by centrifugation for $1 \mathrm{~min}$ at $8000 \times \mathrm{g}$. The standard protocol was modified by changing (i) incubation period with proteinase $\mathrm{K}$ and digestion solution and (ii) percentage of ethanol $(\mathrm{EtOH})$ to make the yield higher. Concentration and purity of DNA was determined using Nano Drop ${ }^{\mathrm{TM}}$ spectrophotometer and the level of fragmentation was assessed from gel electrophoresis.

PCR amplification of DNA isolated from formalin fixed tissue is difficult due to the presence of short fragmented DNA. To overcome this problem, standard composition of PCR reagents was modified to get successful amplification. A regular PCR kit from NEB (E5000S) was used. Initially the reaction was conducted in $25 \mu \mathrm{l}$ volume following the recommended reaction conditions. Primer annealing temperature and extension time was decided according to the melting temperature (Tm) of the primer sets, and amplicon size. One set of primers termed K2N_F1R1 amplified an exon that contains codon 12 of the KRAS and other set was to amplify the region of BRAF that contains codon 600. Amount of template was variable due to variation in DNA concentration and quality. A thermal cycler from Gene Atlas ${ }^{\mathrm{TM}}$ was used for the amplification reaction. Initial PCR amplification from fragmented DNA was unsuccessful, however, modifying template amount, polymerase enzyme concentration in the reaction mixture resulted in successful PCR (section 3.3).

Due to the presence of primer dimers and small genomic DNA fragments, the PCR products were gel extracted using the ATP GelPCR extraction kit (APF100) before sending for sequencing. Briefly, agarose gel slice containing the targeted DNA fragments were excised and transferred into a micro-centrifuge tube. Then $500 \mu \mathrm{l}$ of DF buffer was added to the sample and incubated at $60^{\circ} \mathrm{C}$ for $10-15$ minutes until the gel slice completely dissolved. The lysate was transferred in DF column and centrifuged. Finally the DNA was eluted at $8000 \times \mathrm{g}$ in $15 \mu \mathrm{l}$ water.

DNA extracted from agarose gel was submitted to the departmental sequencing facility. Sequence was received as seqfiles and analyzed using 4Peaks software.

\section{Results and Discussion}

The authors have been able to modify the general purpose GeneJET ${ }^{\text {TM }}$ DNA isolation protocol to increase DNA yield and quality from formalin fixed tissue. They have found 
that increasing the incubation time with proteinase $\mathrm{K}$ and lysis solution and addition of $100 \%$ ethanol instead of 50\% during DNA binding step improved final concentration and purity of DNA extracted from formalin fixed colorectal tissue. After that, PCR amplification of the DNA isolated from the above mentioned samples was also optimized. It was found that two-folds increase in polymerase concentration improved PCR amplification from these fragmented DNA sample. Sequencing of these PCR products after gel extraction generated excellent chromatogram proving that the authors' modification of the protocol was successful to provide quality DNA for clear sequencing.

Standard protocol of the GeneJET ${ }^{\mathrm{TM}}$ kit for mammalian tissue includes incubation of tissue mass (up to $20 \mathrm{mg}$ ) with digestion solution and proteinase $\mathrm{K}$. Considering the protein-protein crosslinking in formalin fixed tissue, the most obvious modification was hypothesized to be longer incubation with proteinase $\mathrm{K}$ that would degrade more protein-protein, protein-DNA crosslink and liberate more DNA. To test this hypothesis, four different incubation periods were examined on a formalin fixed colorectal tissue and a fresh stomach tissue. The fresh tissue was not exposed to formalin and yielded DNA of good quantity and quality through the manufacturer's protocol. This data from fresh tissue served as a control when the present authors compared the effects of incubation time on formalin fixed tissue.

Formalin fixed colorectal cancer tissue digested with lysis solution and proteinase $\mathrm{K}$ at four different time duration (10, 30, 60 and 120 minutes) showed that DNA yield and quality improved with increasing incubation time. However, the same treatment on fresh tissue did not show any visible improvement (Tables 1 and 2; Fig. 2a). This indicates that increasing incubation time improves DNA yield and quality for formalin fixed tissue but have no impacts on fresh tissue. However, although increasing incubation time improved DNA yield from formalin fixed cancer tissue, it was not up to the level of DNA yield from fresh tissue.

Table 1. DNA yield from formalin fixed tissue at different incubation period. C1т1-C1т4: Four time points for colorectal tissue specimen from cancer patient.

\begin{tabular}{cccccc}
\hline $\begin{array}{c}\text { Sample } \\
\text { No. }\end{array}$ & $\begin{array}{c}\text { Mass } \\
(\mathrm{mg})\end{array}$ & $\begin{array}{c}\text { Conc. } \\
(\mathrm{ng} / \mathrm{\mu l})\end{array}$ & $260 / 280$ & $\begin{array}{c}\mathrm{CM} \\
\text { ratio }\end{array}$ & $\begin{array}{c}\text { Incubation } \\
\text { period (min) }\end{array}$ \\
\hline $\mathrm{C} 1 \mathrm{r} 1$ & 17 & 25.5 & 1.19 & 1.5 & 10 \\
$\mathrm{C} 1 \mathrm{~T} 2$ & 15 & 72 & 1.46 & 4.8 & 30 \\
$\mathrm{C} 1 \mathrm{r} 3$ & 17 & 84 & 1.61 & 4.94 & 60 \\
$\mathrm{C} 1 \mathrm{~T} 4$ & 16 & 79 & 1.52 & 4.93 & 120 \\
\hline
\end{tabular}

Gel electrophoresis (Fig. 2a) also supports the above results for formalin fixed cancer tissue. Fresh stomach tissue showed much higher yield as expected. When concentration 
to mass ratio of colorectal cancer tissue was plotted against incubation time, the graph indicated that DNA yield after 60 minutes reached the plateau (Fig. 2b).

Table 2. DNA isolation from fresh stomach tissue specimen at different incubation period. $\mathrm{S}_{\text {T1- }}$ $\mathrm{S}_{\mathrm{T} 3}$ : stomach tissue at three incubation time points. $\mathrm{C} / \mathrm{M}$ ratio $=$ Concentration to tissue Mass ratio.

\begin{tabular}{lcccc}
\hline $\begin{array}{l}\text { Sample } \\
\text { No. }\end{array}$ & $\begin{array}{c}\text { Mass } \\
(\mathrm{mg})\end{array}$ & $\begin{array}{c}\text { Conc. } \\
(\mathrm{ng} / \mathrm{\mu l})\end{array}$ & $260 / 280$ & $\begin{array}{c}\text { Incubation } \\
\text { period }(\min )\end{array}$ \\
\hline $\mathrm{S}_{\text {T1 }}$ & 16 & 280 & 1.96 & 10 \\
$\mathrm{~S}_{\text {T2 }}$ & 15 & 260 & 1.93 & 60 \\
ST3 & 18 & 201 & 1.97 & 120 \\
\hline
\end{tabular}

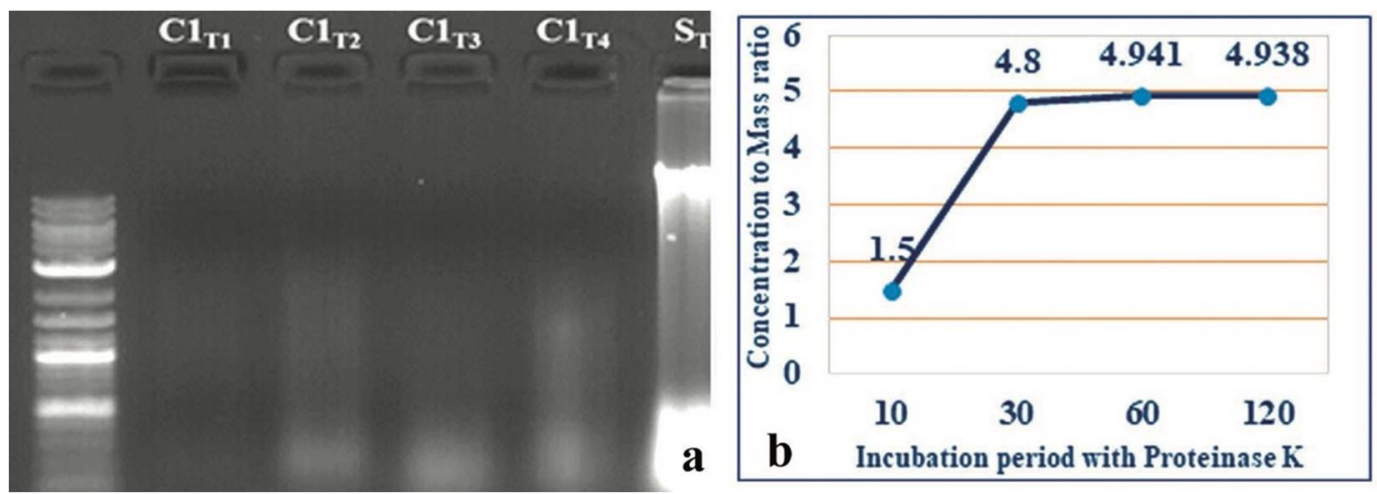

Fig. 2a,b: a. Formalin fixed colorectal tissue (lanes $\mathrm{C}_{1} \mathrm{~T} 1-\mathrm{C} 1 \mathrm{~T} 4$ ) showing increased incubation resulted in higher yield. Fresh stomach tissue $\left(\mathrm{S}_{\mathrm{T} 1}\right)$ has a much higher yield as expected. $b$. Concentration to mass ratio with respect to incubation period with proteinase $\mathrm{K}$. Incubation period plotted on $\mathrm{X}$ axis and concentration to mass ratio on $\mathrm{Y}$ axis.

Based on the concentration to mass ratio, 60 to 120 minutes of incubation was considered ideal for isolation of DNA of sufficient yield and quality. This observation was further validated from another formalin fixed specimen where 1 hour incubation yielded DNA of suitable quality and quantity.

Although increased incubation time had positive impact on DNA yield, not all samples responded in the same way when digested for 60 minutes (Table 3).

To increase the yield from these samples, the sample C5N was incubated for 105 instead of 60 minutes. But it did not have any visible effect in DNA yield (Table 4, samples $\mathrm{C} 5 \mathrm{~N}$ and $\left.\mathrm{C} 5 \mathrm{~N}^{*}\right)$. At this point, it was thought that the increased ethanol concentration might have increased the DNA yield as it helps binding DNA in the column. For this, sample C5 was washed in $100 \%$ ethanol, which gave more than $4 \mathrm{x}$ higher yield than $50 \%$ ethanol (Table 4 , sample $\mathrm{C}^{2} \mathrm{C}^{*}$ ). 
This impact of ethanol concentration became more evident when sample C4 was washed in 50, 75 and 100\% ethanol. All the samples were incubated for 60 minutes. The results showed that ethanol concentration correlated well with the yield of DNA (Fig. 3a).

However, the gel image (Fig. 3b) indicated that the increase in DNA concentration was due to the increase in the amount of fragmented DNA.

Table 3. Genomic DNA isolation from both normal and cancer tissue from patient nos. 4 and 5. $\mathrm{N}$ indicates normal and $\mathrm{C}$ cancer part of colorectal tissue.

\begin{tabular}{cccccc}
\hline Sample & $\begin{array}{c}\text { Mass } \\
(\mathrm{mg})\end{array}$ & $\begin{array}{c}\text { Conc. } \\
(\mathrm{ng} / \mathrm{\mu l})\end{array}$ & $260 / 280$ & $\begin{array}{c}\text { Incubation } \\
(\mathrm{min})\end{array}$ & $\begin{array}{c}\text { EtOH } \\
\text { conc. }(\%)\end{array}$ \\
\hline C4N & 23 & 5 & 1.78 & 60 & 50 \\
C4C & 20 & 5 & 1.79 & 60 & 50 \\
C5N & 18 & 8 & 1.81 & 60 & 50 \\
C5C & 16 & 2.4 & 1.69 & 60 & 50 \\
\hline
\end{tabular}

Table 4. Concentration to mass ratio at $50 \%$ and $100 \% \mathrm{EtOH}$ and different incubation periods.

\begin{tabular}{cccc}
\hline Sample & CM ratio & Incubation $(\mathrm{min})$ & EtOH $(\%)$ \\
\hline $\mathrm{C} 5 \mathrm{~N}$ & 0.444 & 60 & 50 \\
$\mathrm{C}^{*} \mathrm{~N}^{*}$ & 0.645 & 105 & 50 \\
$\mathrm{C}^{*} \mathrm{C}^{*}$ & 2.830 & 105 & 100 \\
\hline
\end{tabular}

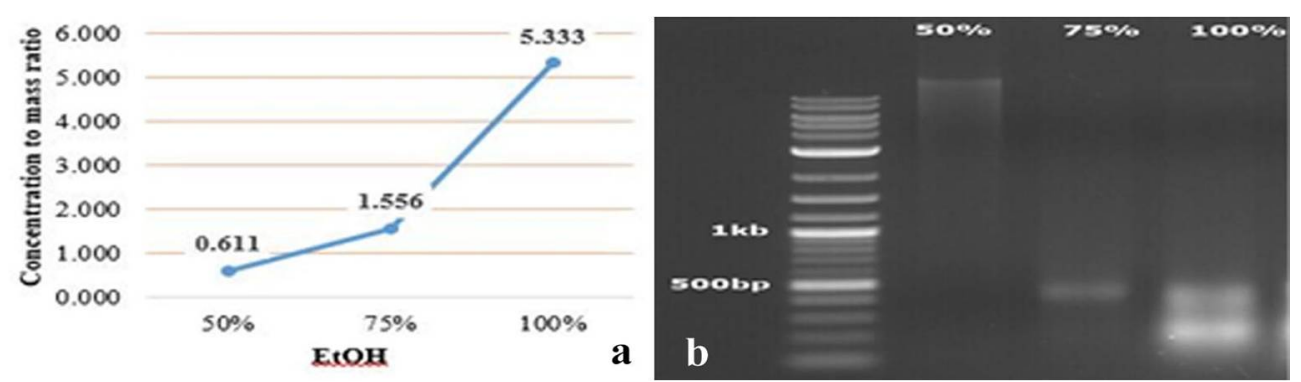

Fig. 3a,b: a. On $\mathrm{X}$ axis percentage of EtOH is plotted and on $\mathrm{Y}$ axis concentration to tissue mass ratio. b. Genomic DNA isolated at different $\mathrm{EtOH}$ concentrations.

Overall, modifications made by the present authors showed that by keeping incubation time for digestion around 60 minutes and homogenization in 100\% alcohol gives better yield of DNA, however the fragmentation due to formalin is irreversible and may depend on exposure and storage condition. To increase the success rate of PCR from such fragmented DNA, they focused on modifying PCR protocol. 
As fragmented DNA is considered as PCR inhibitor and DNA fragmentation could not be prevented in formalin fixed sample, it was expected that sample to sample variation would be observed during PCR amplification. When amplified using primer pair BRAF-F1R1, amplification was successful for cancer tissue of colorectal specimen nos. 1, 2, 4 (C1C, C2C, C4C) but not for specimen nos. 3 and 5 (C3C, C5C) according to standard PCR amplification protocol (Fig. 4a). To solve this issue, first the template volume was increased. Considering the increase in template volume may increase PCR inhibitors in the reaction mixture, it seemed logical to increase polymerase template (Table 5). After the conduction of PCR, gel electrophoresis image showed amplification from both reaction mixtures, although reaction with $0.50 \mu$ l polymerase had more intense band than that of mixture with $0.25 \mu \mathrm{l}$ polymerase (Fig. $4 \mathrm{~b}$ ).

Table 5. PCR amplification of C3C with different polymerase concentration. Primer pair: BRAF F1/R1.

\begin{tabular}{ccccc}
\hline $\begin{array}{c}\text { Product } \\
\text { ID }\end{array}$ & $\begin{array}{c}\text { Final } \\
\text { volume }(\mu \mathrm{l})\end{array}$ & $\begin{array}{c}\text { Template } \\
\text { volume }\end{array}$ & $\begin{array}{c}\text { Polymerase volume } \\
(5 \mathrm{U} / \mu \mathrm{l})\end{array}$ & $\begin{array}{c}\text { Amplifi- } \\
\text { cation }\end{array}$ \\
\hline C3C & 25 & $2 \mu \mathrm{l}$ & 0.125 & No \\
& & $(42.8 \mathrm{ng} / \mu \mathrm{l})$ & & $($ Fig. 4a) \\
C3C' $^{25}$ & $4 \mu \mathrm{l}$ & 0.25 & Yes \\
& 25 & $(42.8 \mathrm{ng} / \mu \mathrm{l})$ & & $($ Fig. $4 \mathrm{~b})$ \\
C3C" $^{\prime \prime}$ & $25 \mu \mathrm{l}$ & 0.50 & Yes \\
& & $(42.8 \mathrm{ng} / \mu \mathrm{l})$ & & $($ Fig. $4 \mathrm{~b})$ \\
\hline
\end{tabular}
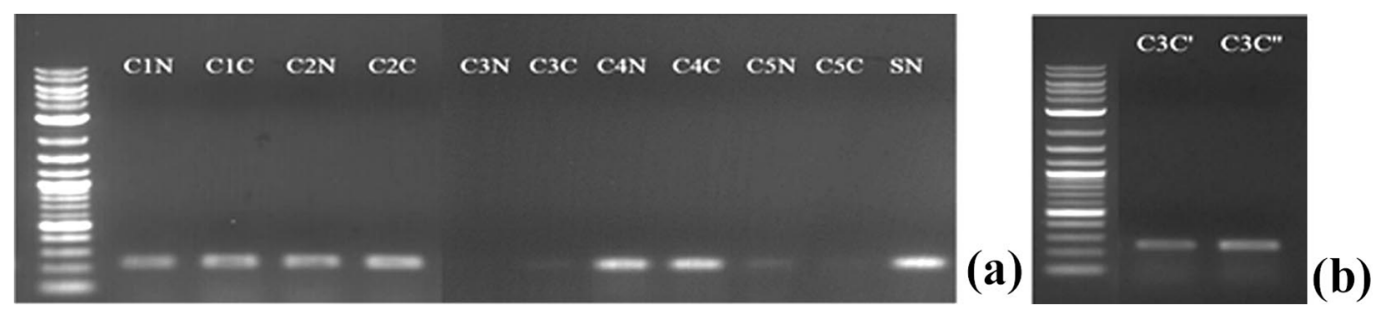

Fig. 4a,b: a. PCR amplification with BRAF-F1/R1 primer pair of both normal and cancer tissue of specimens 1, 2, 3, 4, 5 with standard reaction mixture. C1 - C5: Specimen number, N: normal colon tissue, C: Cancer tissue. It is to be noted that C3 and C5 did not get amplified well in the standard protocol. b. Increasing polymerase amount resulted in successful amplification from C3C with same primer pair.

These data showed that increasing template and polymerase concentration would result in successful PCR if standard PCR does not work for DNA isolated from formalin fixed tissue. It was further evident from successful amplifications of DNA from other specimens: C5, C6 and C7 (Fig. 5i,ii). 

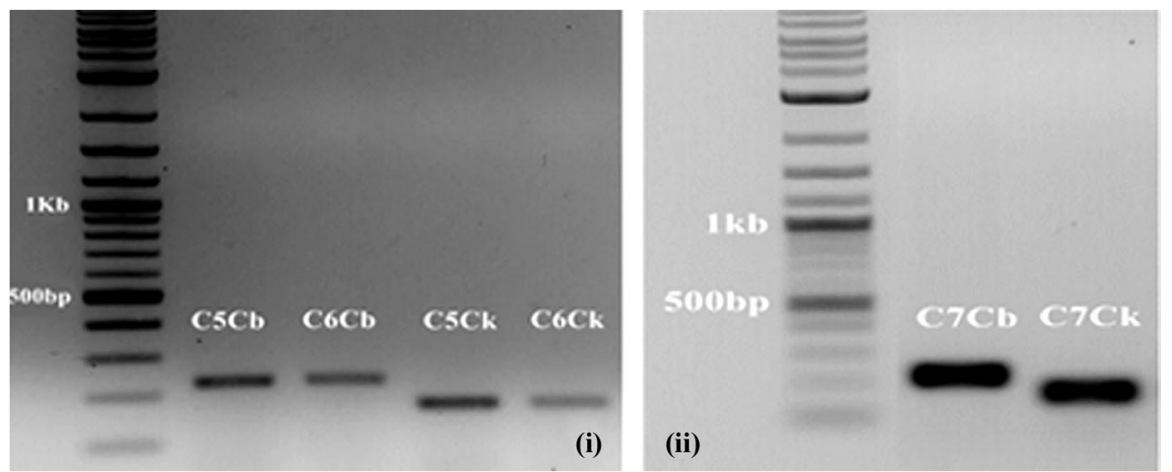

Fig. 5i,ii. Increasing polymerase and template resulted in successful amplification from (i) specimens 5, 6 and (ii) specimen 7. In both images C5-C7 indicates serial numbers of the specimens; the lane numbers with $\mathrm{b}$ indicate samples amplified with $B R A F$ primers pair, and $\mathrm{k}$ indicates samples amplified with KRAS primers pair.

After PCR amplification, the products were purified using gel extraction after electrophoresis and sent for sequencing.

Three cancer specimens (C1, C2 and C7) were sequenced for KRAS and BRAF target mutations using appropriate primers. The chromatogram was reasonably noise free and of good resolution to draw conclusion about the existence of those mutations in the present samples (Figs 6 and 7).

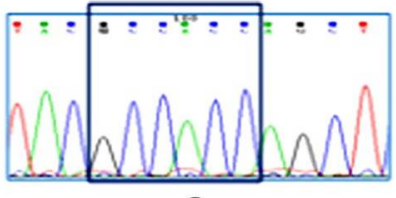

$\mathbf{a}$

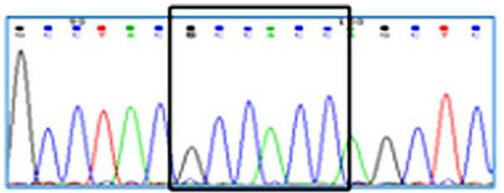

b

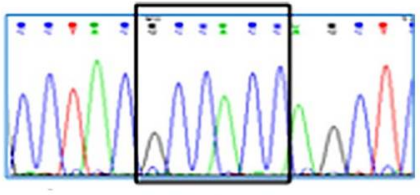

c

Fig. 6. KRAS exon 2 from sample (a) $\mathrm{C} 1 \mathrm{C}$, (b) $\mathrm{C} 2 \mathrm{C}$ and (c) $\mathrm{C} 7 \mathrm{C}$; Boxed regions are of codon 12,13 where the targeted mutations were expected. The sequence showed no mutation in these samples. (a) C1C, (b) C2C and (c) C7C. Boxed regions indicate bases of codon 600 where the target mutation were expected. In these samples, the mutation was absent.
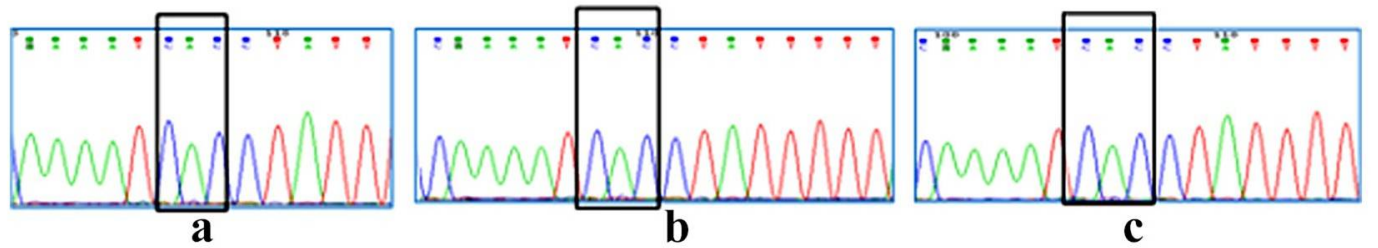

Fig. 7. Sequence of $B R A F$ exon 15 in sample a) $\mathrm{C} 1 \mathrm{C}, \mathrm{b}$ ) $\mathrm{C} 2 \mathrm{C}$ and c) $\mathrm{C} 7 \mathrm{C}$. Boxed regions indicate bases of codon 600 where the target mutation were expected. In these samples, the mutation was absent.

Visual inspection showed that target mutations were not present in the target position, e.g. codon 12/13 in exon 2 for KRAS, and V600E mutation in exon 15 of BRAF 
in those sequenced samples. After performing BLAST (https:/blast.ncbi.nlm.nih.gov/ Blast.cgi), no mutation was detected in any other position within the amplicons in any of the three specimens.

Previously several studies have reported reversal of formalin-induced proteinnucleic acid cross-linkages by thermal energy as well as extended chemical digestion in lung and spleen tissue ${ }^{(13)}$. Moreover, ethanol is reported to enhance DNA precipitation and DNA binding to column ${ }^{(14)}$. Based on those findings, present study investigated the effect of increased incubation period and ethanol for column based DNA extraction protocol and established the role of these modifications for good quality DNA extraction from formalin fixed colorectal tissue. These modifications together with the adjustments in PCR conditions and reagents resulted in successful amplification of target sequence reconfirming previous findings ${ }^{(15)}$.

The results reported here will enable research workers to use regular kits to isolate and sequence DNA from liquid formalin fixed colorectal cancer sample at a much cheaper cost.

\section{Acknowledgement}

The authors gratefully acknowledge UGC research grant for supporting this project and National Institute of Cancer Research and Hospital (NICRH), Dhaka, Bangladesh for providing with study samples.

\section{References}

1. Hussain SMA 2013. Comprehensive update on cancer scenario of Bangladesh. South Asian J. Cancer 2(4): 279-284. doi:10.4103/2278-330X.119901

2. Feldman MY 1973. Reactions of nucleic acids and nucleo proteins with formaldehyde. Translated by A. L. Pumpiansky, Moscow. In: Davidson JN, Cohn WEBT-P in NAR and MB, eds. Vol. 13. Academic Press: 1-49. doi:https://doi.org/10.1016/50079-6603(08)60099-9

3. Puchtler H and Meloan SN 1985. On the chemistry of formaldehyde fixation and its effects on immunohistochemical reactions. Histochem Cell Biol. 82(3): 201-204. doi:10.1007/ bf00501395

4. Srinivasan M, Sedmak D and Jewell S 2002. Effect of fixatives and tissue processing on the content and integrity of nucleic acids. Amer. J. Pathol. 161(6): 1961-1971. doi:10.1016/50002-9440(10)64472-0

5. Chaw YFM, Crane LE, Lange P and Shapiro R 1980. Isolation and identification of cross-links from formaldehyde-treated nucleic acids. Biochemistry 19(24): 5525-5531. doi:10.1021/ bi00565a010

6. Kuykendall JR and Bogdanffy MS 1992. Efficiency of DNA-histone crosslinking induced by saturated and unsaturated aldehydes in vitro. Mutat. Res. 283(2): 131-136.

7. Bonin S, Petrera F, Niccolini B and Stanta G 2003. PCR analysis in archival postmortem tissues. Mol. Pathol. 56(3): 184-186. doi:10.1136/mp.56.3.184 
8. Tariq K and Ghias K 2016. Colorectal cancer carcinogenesis: a review of mechanisms. Cancer Biol. Med. 13(1): 120-135. doi:10.28092 亿.issn.2095-3941.2015.0103

9. Guerrero S, Casanova I, Farre L, Mazo A, Capella G and Mangues R 2000. K-ras codon 12 mutation iduces higher level of resistance to apoptosis and predisposition to anchorageindependent growth than codon 13 mutation or proto-oncogene overexpression. Cancer Res. 60(23): 6750-6756.

10. Sparks AB, Morin PJ, Vogelstein B and Kinzler KW 1998. Mutational analysis of the APC betacatenin/Tcf pathway in colorectal cancer. Cancer Res. 58(6): 1130-1134.

11. Karapetis CS, Khambata-Ford S and Jonker DJ 2008. K-ras mutations and benefit from cetuximab in advanced colorectal cancer. N. Engl. J. Med. 359(17): 1757-1765. doi:10.1056/ NEJMoa0804385

12. Siravegna G, Mussolin B and Buscarino M 2015. Clonal evolution and resistance to EGFR blockade in the blood of colorectal cancer patients. Nat. Med. 21: 795. https://doi.org/ $10.1038 / \mathrm{nm} .3870$.

13. Gilbert MTP, Haselkorn T and Bunce M 2007. The isolation of nucleic acids from fixed, paraffin-embedded tissues-which methods are useful when? PLoS One 2(6): e537. https://doi. org/10.1371 journal.pone.0000537.

14. Gaillard C and Strauss F 1990. Ethanol precipitation of DNA with linear polyacrylamide as carrier. Nucleic Acids Res. 18(2): 378. doi:10.1093/nar/18.2.378

15. Dietrich D, Uhl B and Sailer V 2013. Improved PCR performance using template DNA from formalin-fixed and paraffin-embedded tissues by overcoming PCR inhibition. PLoS One 8(10): e77771. doi:10.1371 łournal.pone.0077771 